Abstracta Iranica Abstracta Iranica

Revue bibliographique pour le domaine irano-aryen

Volume 32-33 | 2013

Comptes rendus des publications de 2009-2010

\title{
Rika Gyselen. Sources arméniennes et sources primaires sassanides : harmonie et dissonance
}

Jullien Cuny

\section{OpenEdition}

1 Journals

Édition électronique

URL : http://journals.openedition.org/abstractairanica/40505

DOI : 10.4000/abstractairanica.40505

ISSN : 1961-960X

\section{Éditeur :}

CNRS (UMR 7528 Mondes iraniens et indiens), Éditions de l'IFRI

\section{Édition imprimée}

Date de publication : 1 décembre 2013

ISSN : 0240-8910

\section{Référence électronique}

Jullien Cuny, « Rika Gyselen. Sources arméniennes et sources primaires sassanides : harmonie et dissonance ", Abstracta Iranica [En ligne], Volume 32-33 | 2013, document 163, mis en ligne le 01 juillet 2016, consulté le 05 octobre 2020. URL : http://journals.openedition.org/abstractairanica/40505 ; DOI : https://doi.org/10.4000/abstractairanica.40505

Ce document a été généré automatiquement le 5 octobre 2020.

Tous droits réservés 


\title{
Rika Gyselen. Sources arméniennes et sources primaires sassanides : harmonie et dissonance
}

\author{
Jullien Cuny
}

\section{RÉFÉRENCE}

Rika Gyselen. « Sources arméniennes et sources primaires sassanides : harmonie et dissonance ", in : M.-A. Amir-Moezzi, J.-D. Dubois, C. Jullien, F. Jullien, éds., Pensée grecque et sagesse d'Orient. Hommage à Michel Tardieu. Brepols, EPHE, 2009, p. 293-306. (Bibliothèque de l'Ecole des Hautes Etudes, section des Sciences religieuses 142)

1 Nouvelle confrontation des sources primaires (sigillographie et numismatique) sassanides et des sources textuelles "externes", ici arméniennes (Faust de Byzance et Sebēos) autour de deux cas. Le premier traite du titre de Dumbāvand vismagān, le second de la chronologie de la carrière du général Sembat Bagratuni et de ses campagnes dans le Khorassan au moment de l'usurpation de Vistahm et d'incursions hephtalites.

\section{AUTEURS}

\section{JULLIEN CUNY}

Conservateur du patrimoine, Lille 